\title{
The Flue Gas Heat Recovery Potential of Buildings
}

\author{
Okan Kon, İsmail Caner \\ Balikesir University Engineering Faculty Department of Mechanical Engineering \\ Cagis Campus 10145 Balikesir, Turkey \\ okan@balikesir.edu.tr: ismail@balikesir.edu.tr
}

\section{Extended Abstract}

In this study, flue gas heat recovery potential of central heating boilers in the heating plant of insulated buildings for four climate zones according to TS 825 (Turkish building insulation standard) has been investigated. The number of buildings to be heated from the heating plants in other words the surface area and volume increase, increases heat requirement. In this case, the recovery potential of the flue gas also increases.

According to TS 825 , indoor temperature is assumed to be $19^{\circ} \mathrm{C}$ and it is calculated that 181 heating days in $1^{\text {st }}$ and $2^{\text {nd }}$ climate regions and 243 heating days in $3^{\text {rd }}$ and $4^{\text {th }}$ climate regions [1]. It is assumed that heating is done 24 hours in a day. It is thought that coal and natural gas are burned as a fuel at the buildings heating plants.

Four different scenarios were considered for each fuel, depending on excess air coefficient and flue gas temperature. For the coal, firstly the air excess coefficient is 2.0 and the flue gas temperature is $200^{\circ} \mathrm{C}$, secondly the air excess coefficient is 2.0 and temperature is $250^{\circ} \mathrm{C}$, thirdly air excess coefficient is 2.5 and temperature is $200^{\circ} \mathrm{C}$, lastly air excess coefficient is 2.5 , the temperature is $250^{\circ} \mathrm{C}$; were assumed. For the natural gas, firstly the air excess coefficient is 1.1 and the flue gas temperature is $150^{\circ} \mathrm{C}$, secondly the air excess coefficient is 1.1 and temperature is $200^{\circ} \mathrm{C}$, thirdly air excess coefficient is 1.6 and temperature is $150^{\circ} \mathrm{C}$, lastly air excess coefficient is 1.6 , the temperature is $200^{\circ} \mathrm{C}$; were assumed [2-5].

In the study, the combustion equations of the fuels were used to calculate the recovery of the flue gas heat of the heating plants. In practice, flue gas temperatures can be reduced to certain values due to sulfurization, corrosion and other reasons. The flue gas temperature for coal can be reduced to minimum $150^{\circ} \mathrm{C}$ and for natural gas this value is $120^{\circ} \mathrm{C}$. These values are above the dew point temperature of coal and natural gas [5,6]. In addition, the flue gas sensible heat and latent heat potentials of the heating plants are calculated [7].

When between 16 to 865 tons of coal is burned for different climatic zones, different air excess coefficient and flue gas temperature; heat recovery potential is change between 3.253 to 412.367 GJ per year. Similarly, when natural gas is burned between 8 to $45210^{6} \mathrm{~m}^{3}$, heat recovery potential is change between 1,924 to 364,729 GJ per year.

As a result, the use of heat recovered from the recovery of flue gases in central heating plants, has been investigated for boiler feeding water and domestic hot water. [8].

Keywords: Insulated Building, Flue Heat Temperature, Heat Recovery, Fuels.

\section{References}

[1] TS 825, "Thermal insulation requirements for buildings", Turkish Standard, May 2008.

[2] M. Terhan, "Research of the heat recovery potential in boiler flue gas relating to the Atatürk University heating," Atatürk University, Graduate School of Natural and Applied Sciences, Department of Mechanical Engineering, Msc Thesis, Erzurum, 2010.

[3] H. Aras, "Doğal gaz yakan sistemlerde baca gazından 1s1 geri kazanımı," Anadolu Üniversitesi, Fen Bilimleri Enstitüsü, Makine Mühendisliği Anabilim Dalı, Yüksek Lisans Tezi, Eskişehir 1991.

[4] Y. A. Çengel, M. A. Boles, "Thermodynamics: An Engineering Approach," McGraw Hill Education, Eight Edition, 2015.

[5] Doğal Gaz-LPG Tesisatı ve Bacalar, Isısan Yayınları, no. 345.

[6] 22. Baca gazlarından 1s1 geri kazanımı, [Online]. Available: www.eie.gov.tr/verimlilik/document/tek_seri_22.doc

[7] O. Kon, B. Yüksel, "Changes of properties in combustion gases due to fuel and combustion air," $13^{\text {th }}$ International Combustion Symposium, Bursa, 2015.

[8] Demir Makina. [Online]. Available: http://www.demirmakina.com/ 